\title{
PEMILIHAN PANTAI PRIORITAS DENGAN PRINSIP COMMUNITY BASED TOURISM DI KAWASAN CLUNGUP MANGROVE CONSERVATION, DUSUN SENDANGBIRU, KABUPATEN MALANG
}

\author{
Akbar Tribowo, M. Yuwana Marjuka, Devi Roza K. Kausar Akbartribowo69@gmail.com \\ Program Studi Pariwisata Fakultas Pariwisata Universitas Pancasila Jl. Srengseng Sawah, Jagakarsa, \\ Jakarta Selatan 12640
}

\begin{abstract}
ABSTRAK
Kawasan wisata Clungup Mangrove Conservation (CMC) secara administrasi terletak di Dusun Sendangbiru, Kecamatan Sumbermanjing Wetan, Desa Tambakrejo, Kabupaten Malang. Didalam kawasan ini terdapat enam pantai yaitu; Pantai Clungup, Pantai Gatra, Pantai Sapana, Pantai Mini, Pantai Batu Pecah, dan Pantai Tiga Warna. Penelitian ini memiliki tujuan untuk memilih pantai prioritas berdasarkan prinsip Community Based Tourism (CBT) sebagai proses pengembangan kawasan wisata, pemilihan pantai prioritas dititikberatkan terhadap empat pantai yaitu; Pantai Clungup, Pantai Sapana, Pantai Mini, dan Pantai Batu Pecah. Dalam proses mendefinisikan pilihan, metode yang digunakan adalah Analytical Hierarchy Process (AHP), untuk menemukan prioritas keriteria dan alternatif. Hasil analisis AHP melibatkan beberapa narasumber terkait sebagai pakar dalam pemangku kepentingan pengembangan kawasan Clungup Mangrove Conservation (CMC). Dari analisis data, terlihat bahwa kriteria prioritas berdasarkan prinsip CBT adalah dimensi lingkungan (0,373), diikuti oleh dimensi ekonomi $(0,330)$, dimensi sosial $(0,172)$, dimensi budaya $(0,076)$, dan terakhir dimensi politik $(0,49)$. Sedangkan alternatif prioritas pemilihan pantai adalah Pantai Clungup dengan skor $(1,000)$ dari masing-masing kriteria. Dengan demikian dapat disimpulkan bahwa pantai yang memiliki prioritas pengembangan adalah Pantai Clungup dengan kepentingan yang berada pada dimensi lingkungan.
\end{abstract}

Kata Kunci: Analytical Hierarchy Process, Kawasan Wisata Pantai, Pakar, Kriteria dan Alternatif.

\section{PENDAHULUAN}

\section{Latar Belakang}

Salah satu prinsip kepariwisataan yang terkandung dalam Undang-undang No 10 Tahun 2009 tentang kepariwisataan adalah memberdayakan masyarakat setempat dimana masyarakat berhak berperan dalam proses pembangunan kepariwisataan dan berkewajiban menjaga dan melestarikan daya tarik wisata; serta membantu terciptanya suasana aman, tertib, bersih, berperilaku santun, dan menjaga kelestarian lingkungan destinasi pariwisata.

Keikutsertaan masyarakat juga dijelaskan dalam undang-undang tersebut diperlukan untuk mendorong pemerataan tantangan perubahan kehidupan lokal, nasional dan global. Hal ini menunjukkan bahwa masyarakat di tingkat lokal memiliki kesempatan yang sama dalam penyelenggaraan kepariwisataan.
Kabupaten Malang memiliki keanekaragaman potensi dan daya tarik wisata yang dapat memicu wisatawan untuk datang ke berbagai destinasi yang ada. Berdasarkan jumlah kunjungan wisatawan mancanegara dan wisatawan nusantara di Kabupaten Malang selama kurun waktu enam tahun dari tahun 2010-2016 mengalamin kenaikan drastis hampir dua kali lipat pada tahun 2016 yaitu sebanyak

5.849.544 kunjungan dari sebelumnya yaitu

3.654.482 kunjungan. Hal ini diperkirakan karena banyaknya wisata pantai di daerah pesisir Malang yang masih sangat asri dan telah banyak diketahui oleh masyarakat umum.

Salah satu diantara banyak wisata pantai di Malang yaitu kawasan Clungup Mangrove Conservation (CMC) yang terletak di Dusun Sendangbiru, Kabupaten Malang yang dikelola oleh masyarakat setempat. Dalam pengelolaannya saat ini di kawasan Clungup Mangrove Conservation terdapat 
enam pantai yaitu, (1) Pantai Clungup, (2) Pantai Gatra, (3) Pantai Sapana, (4) Pantai Mini, (5) Pantai Batu Pecah, (6) Pantai Tiga Warna.

(CMC) dikelola oleh Yayasan Bhakti Alam Sendangbiru, serta terdapat empat stakeholder lain yang berperan dalam pengembangannya yaitu EJEF (East Java Ecotourism Forum), Indecon (Indonesia Ecotourism Network), Sahabat alam Indonesia, serta Pemerintah Desa Tambakrejo. Karena empat stakeholders tersebut berkepentingan maka pengembangan ini dilakukan secara bersama dalam proses pengambilan keputusan didalam aspek ekonomi, sosial, budaya, lingkungan, dan politik.

Berdasarkan jumlah kunjungan wisatawan di Kawasan CMC, kunjungan menurun sebanyak 6.329 wisatawan dari tahun 2016 sebanyak 61.480 wisatawan sampai tahun 2017 sebanyak 55.151 wisatawan. Hal tersebut mengindikasikan bahwa wisatawan dirasa cukup bosan dengan produk yang ada, dimana saat ini hanya tersedia 2 produk utama yaitu Pantai Gatra dan Pantai Tiga Warna. Apabila hal tersebut dibiarkan, maka ini dapat menurunkan kualitas destinasi wisata kawasan Clungup Mangrove Conservation dan bahkan bukan tidak mungkin kawasan CMC ini akan kehilangan wisatawan, seperti apa yang dikatakan oleh Nuryanti dalam wawancaranya kepada travel kompas mengatakan bahwa tanpa produk baru kita akan mengalami product fatique, keletihan produk, jadi susah untuk mendongkrak wisatawan. Jadi, selain promosi yang digenjot, yang lebih penting adalah pembangunan kualitas destinasi.

Fenomena serupa pun pernah terjadi ditempat lain, yaitu Pantai Bangsring, Banyuwangi, pengembangan produk dilakukan untuk mengembalikan ekosistem yang telah rusak sekaligus membentuk Pantai Bangsring sebagai destinasi wisata (Budiman, 2017). Hal tersebut menimbulkan efek pengganda (multiplier effect) seperti pendapat Yoeti (2008) yang menyatakan bahwa uang yang dibelanjakan wisatawan, setelah dibelanjakan tidak berhenti beredar, akan tetapi berpindah dari satu tangan ke tangan orang lain atau dari satu perusahaan ke perusahaan lain (yang berkaitan dengan pariwisata). Fenomena ini sangat selaras dengan apa yang terjadi pada kawasan Clungup Mangrove Conservation, dimana kawasan ini sangat memerlukan pengembangan produk demi meningkatkan jumlah kunjungan dan dampak positif lainnya.

Pantai yang menjadi bagian dalam pengembangan produk yaitu Pantai Clungup, Pantai Sapana, Pantai Mini, dan Pantai Batu Pecah. Ke empat pantai ini yang akan dikembangkan oleh pengelola kawasan. Skema pengembangan telah dilakukan oleh pengelola kawasan namun, belum adanya prioritas pemilihan pantai dan juga wilayah yang dikaji belum memiliki akses sehingga pengembangan produk dimaksudkan dibatasi sebatas pemilihan pantai. Artinya pengelola belum melihat seberapa penting sebuah pantai yang ada untuk dilakukan sebuah pengembangan produk pariwisata sehingga manfaat yang dihasilkan dapat maksimal

Untuk mengetahui bagaimana pemilihan pantai prioritas di Kawasan Clungup Mangrove Conservation dengan prinsip Community Based Tourism (CBT) dibutuhkan beberapa aspek utama pengembangan CBT. Menurut Suansri (2003) aspek pengembangan CBT berupa lima dimensi yaitu dimensi ekonomi, dimensi sosial, dimensi budaya, dimensi lingkungan, dan dimensi politik. Oleh karena itu, penting untuk terlebih dahulu mengetahui sejauh mana penerapan prinsip CBT di kawasan CMC dalam hal ini adalah Pantai Clungup, Sapana, Mini, dan Batu Pecah.

\section{TINJAUAN PUSTAKA}

\section{Pengertian Pariwisata}

Spillane (2003) mendefinisikan pariwisata sebagai "perjalanan dari satu tempat ke tempat lain, bersifat sementara, dilakukan perorangan maupun kelompok, sebagai usaha mencari keseimbangan hidup dalam dimensi sosial, budaya, alam dan seni". Pendapat ini diamini oleh Suwantoro (2004) yang menyatakan bahwa perjalanan wisata merupakan suatu perjalanan yang dilakukan oleh seseorang atau lebih dengan tujuan antara lain untuk mendapatkan kenikmatan dan memenuhi hasrat ingin sesuatu. Pendapat lain disampaikan oleh Damanik dalam Suwantoro (2004) bahwa pariwisata adalah fenomena pergerakan manusia, barang, dan jasa, yang sangat 
kompleks. Ia terkait erat dengan organisasi, hubungan-hubungan kelembagaan dan individu, kebutuhan layanan, penyediaan kebutuhan layanan, dan sebagainya.

Menurut Sihite dalam Suwantoro (2004), pariwisata adalah suatu perjalanan yang dilakukan orang untuk sementara waktu, yang diselenggarakan dari suatu tempat ke tempat lain meninggalkan tempatnya semula, dengan suatu perencanaan dan dengan maksud bukan untuk berusaha atau mencari nafkah di tempat yang dikunjungi, tetapi semata-mata untuk menikmati kegiatan pertamasyaan dan rekreasi atau untuk memenuhi keinginan yang beraneka ragam. Secara luas pengertian pariwisata dikemukakan oleh Goeldner dalam Suwantoro (2004), pariwisata adalah kombinasi aktivitas, pelayanan dan industri yang menghantarkan pengalaman perjalanan: transportasi, akomodasi, usaha makanan dan minuman, toko, hiburan, fasilitas aktivitas dan pelayanan lainnya yang tersedia bagi perorangan atau grup yang sedang ,melakukan perjalanan jauh dari rumah. Menurut Undang-Undang Nomor

10 Tahun 2009 pariwisata adalah berbagai macam kegiatan wisata dan didukung berbagai fasilitas serta layanan yang disediakan oleh masyarakat, pengusaha, pemerintah, dan Pemerintah Daerah.

Dari pengertian-pengertian di atas, dapat disimpulkan bahwa pariwisata merupakan perjalanan yang dilakukan manusia ke daerah yang bukan merupakan tempat tinggalnya dalam waktu paling tidak satu malam dengan tujuan perjalanannya bukan untuk mencari nafkah, pendapatan atau penghidupan di tempat tujuan. Pariwisata adalah suatu perjalanan yang dilakukan untuk sementara waktu dari satu tempat ke tempat lain yang mempunyai obyek dan daya tarik wisata untuk dapat dinikmati sebagai suatu rekreasi atau hiburan yang mendapatkan kepuasan lahir dan batin.

Pengertian Pariwisata Berbasis Masyarakat Adimihardja, 1999 dalam Sunaryo (2013) mendefinisikan pemberdayaan masyarakat sebagai suatu proses yang tidak sengaja hanya mengembangkan potensi ekonomi masyarakat yang sedang tidak berdaya, namun demikian juga harus berupaya dapat meningkatkan harkat dan bartabat, rasa percaya diri dan harga dirinya serta terpeliharanya tatanan nilai budaya setempat. Pemberdayaan masyarakat dimaknai sebagai suatu upaya untuk menguatkan power (daya) atau empowering dari golongan masyarakat yang powerless (tidak berdaya), biasanya mereka yang sedang tergolong ke dalam masyarakat yang marjinal.

Sunaryo (2013) menyatakan bahwa untuk mewujudkan pengembangan pariwisata berjalan dengan baik dan dikelola dengan baik maka hal yang paling mendasar dilakukan adalah bagaimana memfasilitasi keterlibatan yang luas dari komunitas lokal dalam proses pengembangan dan memaksimalkan nilai manfaat sosial dan ekonomi dari kegiatan pariwisata untuk masyarakat setempat. Masyarakat lokal memiliki kedudukan yang sama pentingnya sebagai salah satu pemangku kepentingan (stakeholder) dalam pembangunan kepariwisataan, selain pihak pemerintah dan industri swasta.

Pentingnya pemberdayaan masyarakat dalam pengembangan kepariwisataan menjadi sorotan penting menurut pakar kepariwisataan dunia. Murphy, 1988, Dwyer et al., 2010 dalam Sunaryo, (2013) pembangunan kepariwisataan harus merupakan suatu kegiatan yang berbasis pada komunitas, dengan faktor utama bahwa sumber daya dan keunikan komunitas lokal baik berupa elemen fisik maupun non fisik (tradisi dan budaya) yang melekat pada komunitas tersebut harus menjadi penggerak utama dalam pariwisata tersebut.

Menurut Suansri (2003) mendefinisikan CBT sebagai pariwisata yang memperhitungkan aspek keberlanjutan lingkungan, sosial, dan budaya. CBT merupakan alat pembangunan komunitas dan konservasi lingkungan. Dengan kata lain CBT merupakan alat untuk mewujudkan pembangunan pariwisata yang berkelanjutan. Aspek utama pengembangan CBT berupa 5 dimensi, yaitu :

1. Dimensi Ekonomi, dengan indikator berupa adanya dana untuk pengembangan komunitas, terciptanya lapangan pekerjaan di sektor pariwisata, dan timbulnya pendapatan masyarakat lokal dari sektor pariwisata.

2. Dimensi Sosial, dengan indikator meningkatnya kualitas hidup; peningkatan kebanggaan komunitas; pembagian peran yang adil antara lakilaki, perempuan, generasi muda, dan tua; membangun penguatan organisasi komunitas.

3. Dimensi budaya, dengan indikator berupa mendorong masyarakat untuk menghormati budaya yang berbeda, membantu berkembangnya pertukaran budaya, budaya pembangunan melekat erat dalam budaya lokal. 
4. Dimensi lingkungan, dengan indikator mempelajari carrying capacity area, mengatur pembuangan sampah,

meningkatkan kepedulian akan perlunya konservasi.

5. Dimensi politik, dengan indikator: meningkatkan partisipasi dari penduduk lokal, peningkatan kekuasaan komunitas yang lebih luas, menjamin hak-hak dalam pengelolaan sumber daya alam.

Suansri (2003) menyebutkan beberapa prinsip dari community based tourism yang harus dilakukan, yaitu: 1) mengenali, mendukung, dan mempromosikan kepemilikan masyarakat dalam pariwisata; 2) melibatkan anggota masyarakat dari setiap tahap pengembangan pariwisata dalam berbagai aspeknya; 3) mempromosikan kebanggaan terhadap komunitass lokal bersangkutan; 4) meningkatkan kualitas hidup; 5) menjadi keberlangsungan lingkungan; 6) melindungi ciri khass (keunikan) dan budaya masyarakat lokal; 7) mengembangkan pembelajaran lintas budaya; 8) menghormati perbedaan budaya dan martabat manusia; 9) mendistribusikan keuntungan dan manfaat yang diperoleh secara proposional kepada anggota masyarakat; 10) memberikan kontribusi denga perstentase tertentu dari pendapatan yang diperoleh untuk pengembangan masyarakat; dan 11) menonjolkan keaslian hubungan masyarakat dengan lingkungannya.

Berdasarkan pendapat beberapa ahli terkait CBT di atas terlihat bahwa Community-Based Tourism atau pariwisata berbasis masyarakat sangat berbeda dengan pengembangan pariwisata pada umumya (mass tourism). Dalam CBT masyarakat merupakan aktor utama dalam menggerakan roda kepariwisataan, dengan tujuan utama untuk peningkatan standar kehidupan manusia dan menjaga kestabilan ekosistem yang ada.

\section{Pengertian Analytical Hierarchy Process \\ (AHP)}

Analytical Hierarchy Process (AHP) adalah sebuah hierarki fungsional dengan input utamanya adalah persepsi manusia. Dengan hierarki, suatu masalah kompleks dan tidak terstruktur dipecahkan ke dalam kelompokkelompoknya. Kemudian kelompok-kelompok tersebut diatur menjadi suatu bentuk hierarki (Mulyono, 2004). AHP adalah pendekatan dasar untuk pengambilan keputusan. AHP didesain untuk menanggulangi rasional dan intuisi untuk memilih yang terbaik dari alternarif-alternatif yang di evaluasi dengan beberapa kriteria. Dalam proses ini pembuatan keputusan menggunakan pairwise comparison judgement yang digunakan untuk membentuk seluruh prioritas untuk mengetahui ranking dari alternatif. Secara sederhana, AHP sering diartikan sebagai pembobotan (penentu prioritas) dari serangkaian persoalan yang dihadapi, baik terhadap kriteria maupun alternatifnya (Bustanul, 2010).

AHP dikembangkan tahun 1970 oleh Thomas L. Saaty, seorang ahli matematika dari Amerika Serikat. Dalam perkembangannya tidak saja digunakan untuk menentukan prioritas pilihan-piihan dengan banyak kriteria, tetapi penerapanna telah meluas sebagai metode alternatif untuk menyelesaikan bermacam-macam masalah seperti memilih portofolio, peramalan dan lain-lain. Dengan metode AHP ini memungkinkan kita untuk mengambil keputusan secara efektif terhadao persoalan yang kompleks dimana faktorfaktor logika, intuisi, pengalaman, pengetahuan data, emosi dan rasa dioptimasikan dalam suatu proses yang sistematis (Mulyono, 2004).

Sumber kerumitan masalah keputusan bukan hanya ketidakpastian atau ketidaksempurnaan informasi. Penyebab lainnya adalah banyaknya faktor yang berpengaruh terhadap pilihan- pilihan yang ada, beragamnya kriteria pemilihan dan jika pengambilan keputusan lebih dari satu (Mulyono, 2004). Terkadang timbul masalah keputusan yang dirasakan dan diamati perlu diambil secepatnya, tetapi variasinya cukup rumit sehingga datanya tidak mungkin dapat diolah menjadi numerik, hanya kualitatif saja yang dapat diukur yaitu berdasarkan persepsi pengalaman dan intuisi.

Prinsip kerja AHP adalah dengan menyederhanakan suatu persalan kompleks yang tidak terukur, stratejik dan dinamik menjadi sebuah bagian-bagian dan tersusun dalam satu hierarki. Tingkat kepentingan setiap variabel diberi nilai numerik, secara subjektif tentang arti penting variabel tersebut dan secara relatif dibandingkan dengan variabel lain. Dengan membuat struktur keputusan yang sistematis dan serangkaian prosedur perhitungan, maka dapat dihasilkan rekomendasi prioritas atau bobot keputusan tiap alternatif yang diajukan. Dari berbagai pertimbangan kemudian dilakukan sintesa untuk menetapkan variabel yang memiliki prioritas tinggi dan berperan dalam 
mempengaruhi hasil pada sistem tersebut (Mulyono, 2004).

\section{METODE PENELITIAN}

Pendekatan yang digunakan dalam penelitian ini adalah pendekatan kualitatif, yaitu penelitian yang tidak menggunakan perhitungan, atau diistilahkan dengan penelitian ilmiah yang menekankan pada karakter alamiah sumber data (Moleong, 2002). Sedangkan Sukmadinata (2007) mengatakan penilitian kualitatif yaitu suatu penelitian yang ditujukan untuk mendeskripsikan dan menganalisis fenomena, peristiwa, aktivitas sosial, sikap, kepercayaan, persepsi, pemikiran orang secara individu maupun kelompok. Dalam penelitian kualitatif ini digunakan untuk menggambarkan tanggapan responden terhadap obyek berdasarkan kuesioner yang diberikan serta relevan dengan variabelvariabel yang diteliti.

Pada penerapan metode AHP yang diutamakan adalah kualitas data dari responden, dan tidak tergantung pada kuantitasnya (Saaty, 1993). Oleh karena itu, penilaian AHP memerlukan pakar sebagai responden dalam pengambilan keputusan dalam pemilihan alternatif. Para pakar disini merupakan orang-orang kompeten yang benarbenar menguasai, mempengaruhi pengambilan kebijakan atau benar-benar mengetahui informasi yang dibutuhkan. Untuk jumlah responden dalam metode AHP tidak memiliki perumusan tertentu, namun hanya ada batas minimum yaitu dua orang responden (Saaty, 1993).

Teknik pengambilan data sampel ini didasarkan oleh pertimbangan tertentu, misalnya keterbatasan waktu, tenaga dan dana sehingga tidak dapat mengambil sampel yang besar dan jauh. Adapaun cara dalam penentuan sampel, penulis menggunakan cara pusposive sampling. Hal ini dilakukan dengan cara mengambil subjek bukan didasarkan atas strata, random atau daerah tetapi didasarkan atas adanya tujuan atau pertimbangan tertentu (Sugiyono, 2009), dengan kriteria mewakili setiap bidang keahlian dan diprioritaskan kepada pakar yang disyaratkan untuk menggunakan AHP cukup beberapa orang (Saaty, 1993). Para pakar tersebut adalah para decision maker yang terlibat aktif dalam pengembangan Kawasan
Clungup Mangrove Conservation yaitu; (1) Yayasan Bhakti Alam Sendangbiru berperan sebagai pengelola, dalam hal ini yayasan tersebut cukup mengerti terkait semua dimensi yang ada dalam aspek pengembangan CBT karena yayasan ini adalah bagian dari masyarakat setempat, (2) EJEF (East Java Ecotourism Forum), organisasi ini berfokus terhadap perjuangan pariwisata di Jawa Timur yang berkelanjutan menuju kelestarian alam melalui ekowisata, dengan kata lain organisasi ini berperan sebagai pihak yang memberi saran dan masukan terhadap pengembangan di kawasan Clungup Mangrove Conservatoin dalam bidang lingkungan, (3) Indecon (Indonesia Ecotourism Forum) yang berperan untuk membina anggota Yayasan Bhakti Alam Sendangbiru dalam mengelola destinasi serta pengembangan kawasan CMC di berbagai aspek mulai dari sosial, lingkungan, budaya sampai ekonomi, (4) Sahabat Alam Indonesia berperan dalam melakukan perlindungan hutan dan laut di kawasan CMC dalam bentuk pengawasan serta melakukan riset terhadap berbagai jenis burung yang nantinya akan dijadikan atraksi wisata tambahan di kawasan CMC, dengan demikian dalam penelitian ini organisasi tersebut lebih berperan terhadap aspek lingkungan, (5) Pemerintah Desa Tambakrejo sebagai regulator dalam pengembangan kawasan $\mathrm{CMC}$, peran ini melengkapi dari semua peran yang ada pada stakeholder di kawasan CMC, selain itu, pemerintah desa dalam rangka menyelenggarakan otonomi daerah memiliki tujuan untuk meningkatkan kesejahteraan masyarakat dan memperhatikan potensi dan keanekaragaman daerah, namun sayangnya pengetahuan terkait aspek lingkungan terbilang kurang, maka dari itu dalam penelitian ini Pemerintah Desa Tambakrejo cenderung memahami dalam aspek ekonomi, sosial, budaya, dan politik.

Untuk menganalisis data yang telah terkumpul selanjutnya akan dianalisis secara kualitatif dan kuantitatif yang disajikan dalam bentuk tabel, bagan dan uraian. Analisis kualitatif dilakukan secara deskriptif berdasarkan hasill kuantitatif, sedangkan analisis kuantitatif yang dihasilkan berupa bobot, rating dan skor. Untuk mengetahui Pantai yang akan menjadi prioritas pengembangan menggunakan alat analisis Analitycal Hierarcy Process (AHP). 


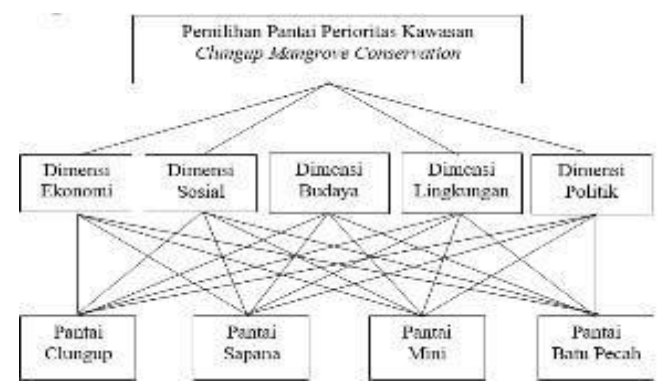

Struktur Hirarki Pemilihan Kawasan Pantai Sumber: Hasil Penelitian

Validasi data yang digunakan dalam penelitian ini dengan menggunakan rasio konsistensi, AHP sebagai alat pengambil keputusan telah dikonfirmasi dengan membandingkan antar masing-masing kriteria dan alternatif. Validasi data dikatakan berhasil apabila nilai inkonsistensi dibawah 0,10 maka nilai dikatakan konsisten. Dengan demikian, apabila nilai inkonsistensi di atas 0,10 dianggap gugur/tidak dipakai.

\section{HASIL DAN PEMBAHASAN}

\section{Gambaran Umum Lokasi Penelitian}

Dusun Sendangbiru berada di Desa Tambakrejo, Kecamatan Sumbermanjing Wetan, Kabupateng Malang, yang terdiri dari dua dusun yaitu Dusun Tambakrejo dan Dusun Sendangbiru. Dusun Sendangbiru merupakan daerah pesisir pantai dengan wilayah pantainya yang berhadapan langsung dengan Pulau Sempu. Panjang garis pantai Kabupaten Malang secara keseluruhan adalah $85,92 \mathrm{~km}$ dengan luas perairan laut $4 \mathrm{mil}$ sekitar $565,45 \mathrm{~km}^{2}$ atau luas perairan 12 mil sekitar 1696,35 $\mathrm{km}^{2}$. Panjang garis pantai Sumbermanjing Wetan sekitar 27,02 km, dengan luas perairan laut 4 mil sekitar $176,76 \mathrm{~km}^{2}$ dan luas perairan

12 mil sekitar 536,29 km² (Sumber: Kantor Desa Tambakrejo, 2016).

Dengan luasnya perairan yang dimiliki oleh Dusun Sendangbiru bukan hanya menjadi potensi bagi kegiatan wisata saja, bahkan dalam sektor perikanan memiliki potensi yang cukup melimpah. Pada dasarnya Dusun Sendangbiru merupakan salah satu tujuan wisata bagi masyarakat di sekitar Kota Malang karena Sendangbiru memiliki panorama alam yang indah. Hal tersebut ditunjang dengan adanya Pulau Sempu yang memiliki fungsi sebagai cagar alam atau break water alami dan penghalang kencangnya gelombang dari arah timur lepas. Perairan Sendangbiru memiliki kedalaman ratarata 1.000 meter. Perairan ini berbatasan langsung dengan Samudera Hindia, sehingga memiliki gelombang yang relatif besar terutama pada daerah-daerah yang masuk ke pantaipantai yang curam dan terjal. Namun, dengan adanya Pulau Sempu maka Pantai yang berada di Sendangbiru relatif aman, sehingga pada saat ini oleh pemerintah setempat dimanfaatkan sebagai tempat wisata dan pusat produksi perikanan Kabupaten Malang. Beberapa destinasi wisata yang berada di Dusun Sendangbiru maupun sekitarnya antara lain: Pulau Sempu, Pantai Sendiki, Pantai Sendangbiru, Pantai Pasir Panjang, Pantai Clungup, Pantai Gatra, Pantai Sapana, Pantai Mini, Pantai Batu Pecah, dan Pantai Tiga Warna. Banyaknya destinasi wisata di Sendangbiru membuat pilihan bagi wisatawan yang akan datang, sehingga menjadi alternatif bagi wisatawan apabila salah satu pantai sedang padat pengunjung. Pada umumnya pantaipantai yang berada di Sendangbiru dikelola oleh komunitas masyarakat setempat, termasuk Pantai Clungup, Pantai Gatra, Pantai Sapana, Pantai Mini, Pantai Batu Pecah, dan Pantai Tiga Warna yang di kelola oleh sebuah komunitas lokal berbadan yayasan yaitu Yayasan Bhakti Alam Sendangbiru dengan menjadikan ke enam pantai tersebut menjadi satu kawasan yaitu kawasan Clungup Mangrove Conservation.

Lembaga Masyarakat Konservasi Bhakti Alam Sendangbiru sebagai pengelola kawasan Clungup Mangrove Conservation dengan luas lahan 117 ha, 81 ha diantaranya adalah kawasan hutan mangrove yang mana 73 ha kawasan hutan mangrove telah direhabiltasi, dengan batas-batasnya serta daya tarik kawasan CMC sebagai berikut.

\begin{tabular}{|l|l|}
\hline Sebelah Barat & Desa Sitiarjo \\
\hline Sebelah Timur & $\begin{array}{l}\text { Kampung Baru dan TPI } \\
\text { Sendangbiru }\end{array}$ \\
\hline Sebelah Utara & $\begin{array}{l}\text { Perkebunan Milik } \\
\text { Warga }\end{array}$ \\
\hline Sebelah Selatan & $\begin{array}{l}\text { Pulau Sempu dan } \\
\text { Samudra Hindia }\end{array}$ \\
\hline
\end{tabular}

Batas Lokasi Kawasan CMC Sumber: Yayasan Bhakti Alam Sendangbiru 


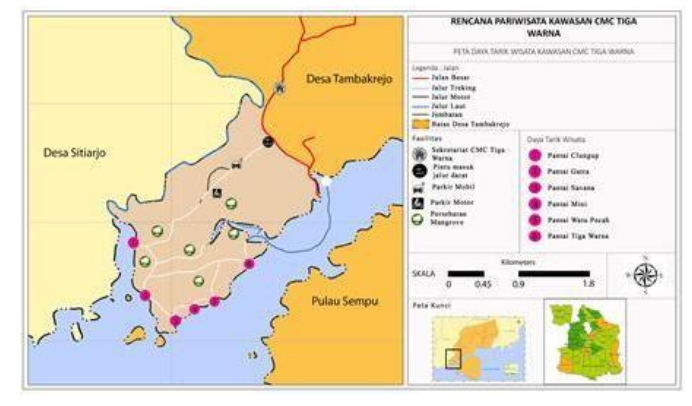

Peta Daya Tarik Kawasan CMC Sumber: BIG (diolah pribadi)

\section{Perkembangan Kawasan Clungup Mangrove Conservation}

Berawal pada masa reformasi 1998 yang lepas kendali menjadi biang kerusakan lingkungan di pesisir selatan Jawa Timur, termasuk hutan mangrove di pesisir Pantai Clungup, serta keanekaragaman hayati yang ada. Lahan yang ada menjadi lahan pertanian sekitar 81 hektar, yang diakibatkan karena masyarakat turut adil dalam penebangan yang terjadi.

Ketergantungan masyarakat terhadap hasil laut juga sangat besar. Hal ini dibuktikan dengan semakin banyaknya masyarakat pendatang yang menetap di Sendangbiru sebagai nelayan atau pegusaha ikan. Keadaan ini menimbulkan kesenjangan sosial, semakin minimnya sumberdaya laut, dan degradasi lingkungan yang drastis. Keadaan inilah yang mendorong sebagian masyarakat untuk memberdayakan dirinya pada sektor usaha yang lain.

Berangkat dari hal inilah munculnya gerakan masyarakat yang di awali dengan rehabilitasi dan konservasi mangrove di Pantai Clungup dalam upaya merestorasi kawasan Pantai Clungup di awali oleh Bapak Saptoyo seorang diri, dengan melakukan penghijauan penanaman bibit mangrove kawasan Pantai Clungup yang terjadi pada tahun 2005-2011, hingga pada 24 Oktober 2014 resmi terbentuk Lembaga Masyarakat Konservasi Bhakti Alam Sendangbiru.

Yayasan Bhakti Alam Sendangbiru berdiri atas inisiatif Bapak Saptoyo, Lia Putrinda, dan Aditya Rheza selaku pendiri yayasan yang dilatar belakangi oleh kerusakan alam yang terjadi di kawasan mangrove. Pada tahun 2012 mulai terbentuknya POKMASWAS GOAL guna mengawasi lingkungan pesisir seperti kawasan hutan mangrove serta pantai. Kemudian pada tahun 2014 mulai berkembang untuk aktifitas lebih dari pengawasan pesisir. Setelah berjalannya aktifitas-aktifitas tersebut, perlahan inisiator dan anggota POKMASWAS
GOAL Sendangbiru mulai menyebarkan "virus" kepedulian terhadap lingkungann kepada masyarakat setempat.

Pada tanggal 24 Oktober 2014 berdirilah yayasan ini guna meningkatkan kelestarian lingkungan. Tidak hanya berfokus pada pengawasan saja melainkan upaya-upaya yang dapat dilakukan masyarakat setempat dan masyarakat umum (wisatawan) untuk ikut serta dalam pelestarian lingkungan. Hingga kini, kegiatan konservasi yang dilakukan oleh Yayasan Bhakti Alam Sendangbiru semakin besar seiring pengelolaan kawasan mangrove, pesisir, dan pantai dengan konsisten. Kegiatan yang lebih fokus pada konservasi mangrove melahirkan gerakan baru dari Yayasan Bhakti Alam Sendangbiru yang berlabel Clungup Mangrove Conservation. Sesuai dengan namanya, pengelolaan Clungup Mangrove Conservation tidak berorientasi pada bisnis melainkan pada ekologi, sosial, dan ekonomi. Bahkan, kegiatan wisatawan pun terus dipantau sehingga tidak ada kegiatan wisatawan yang dapat menimbulkan kerusakan lingkungan.

\section{Penerapan Prinsip Community Based Tourism di Pantai Clungup, Pantai Sapana, Pantai Mini, dan Pantai Batu Pecah}

Dalam penerapan CBT pada suatu daerah wisata, diperlukan berbagai aspek-aspek pendukung baik itu aspek fisik maupun sosial. Aspek fisik yang terdapat di kawasan Clungup Mangrove Conservation ini berupa banyaknya pantai yang indah dengan potensi untuk dikelola. Meskipun pantai-pantai yang berpotensi untuk dikelola tersebut banyak namun tetap dalam pengelolaannya yang beraspek berkelanjutan. Pembangunan pariwisata berkelanjutan dan tentunya berpegang teguh pada prinsip CBT dipengaruhi beberapa aspek yang tidak bisa dihindari, mulai dari aspek ekonomi, sosial, budaya, lingkungan hingga politik.

1. Dimensi Ekonomi

Berdasarkan pengamatan di lapangan serta keterangan yang peneliti peroleh dari responden, didapatkan bahwa pengelolaan wisata kawasan Clungup Mangrove Conservation, telah dikelola dengan prinsip ekonomi, dimana pada wisata kawasan CMC ini telah mampu menghimpung dan memanfaatkan dana untuk pengembangan komunitas dari beberapa sumber dan dalam perkembanganannya menggunakan hasil operasional kelompok yaitu dari retribusi pengunjung setiap bulannya. Adanya masyarakat yang terlibat dalam 
keanggotaan Yayasan Bhakti Alam Sendangbiru mengisyaratkan bahwa ada jenis pekerjaan yang ditentukan berdasarkan standar pelayanan oleh pengelola kemudian dari masyarakat melihat adanya peluang untuk mengambil keuntungan didalamnya dengan membuka beberapa usaha, usaha ini meliputi homestay, rumah makan, dan ojek

\section{Dimensi Sosial}

Manfaat yang diterima oleh masyarakat Dusun Sendangbiru, jika ditinjau dari aspek sosial dimana manfaat ini dirasakan setelah adanya perubahan status lahan dari lahan tambak menjadi lahan konservasi.

Peningkatan kebanggaan komunitas telihat dengan adanya kebersamaan kelompok ini dengan masyarakat setempat dalam melayani pengunjung sebagi suatu masyarakat yang masih mengunjungi tinggi semangat kekeluargaan dan kebersamaan. Mereka berusaha memberikan pelayanan yang terbaik bagi para pengunjung untuk memberikan kesan sebagai tuan rumah yang baik, dalam melibatkan masyarakat, Yayasan Bhakti Alam Sendangbiru ini tidak mendeskriminasi gender dan umur dengan tetap menempatkan posisi sesuai dengan status dan perannya masing-masing.

\section{Dimensi Budaya}

Berdasarkan hasil observasi dilapangan dan wawancara terhadap expert terdapat prinsip budaya di dalam pengelolaan kawasan Clungup Mangrove conservation, dimana kawasan CMC ini melakukan tutup kunjungan pada saat hari raya keagamaan, hal tersebut dilakukan untuk menunjukkan nilai toleransi antar umat beragama di Dusun Sendangbiru. Khusus di Pantai Clungup terdapat tempat terlaksananya kegiatan ambal warso sebagai bentuk memperingati lahirnya semangat perjuangan yang sudah dibentuk dengan ketulusan dan rasa ikhlas dalam semangat kebersamaan Yayasan Bhakti Alam Sendangbiru dalam merestorasi dan mengelola kawasan CMC, kegiatan ini dilaksanakan setiap tanggal 21 September. Kegiatan ini memberikan nilai-nilai kebudayaan dan kebersamaan dalam pelaksanaannya, sehingga menjadi daya tarik tersesendiri bagi wisatawan yang datang bertempatan dengan tanggal tersebut.
4. Dimensi Lingkungan

Phillips (2009) mengatakan sektor pariwisata selain dapat menyediakan keuntungan ekonomi, sosial maupun budaya, juga dapat membantu mencapai sasaran konservasi lingkungan. Kawasan Clungup Mangrove Conservation menerapkan pembatasan jumlah kunjungan dalam satu waktu, pengelola hanya memperbolehkan 100 orang dalam satu waktu. Demi terciptanya alam yang bersih, pengelola tidak hanya menerapkan batasan kunjungan tapi juga turut mengatur pembuangan sampah. Pengaturan sampah diterapkan pada saat wisatawan mendaftar ulang di pos registrasi, wisatawan wajib didata barang bawaan yang berpotensi menjadi sampah yang akan dibawa masuk, ketika nanti wisatawan akan meninggalkan kawasan CMC wisatawan kembali di cek sampah-sampah yang dibawa, apabila jumlah sampah tidak sesuai dengan pengecekan pertama makan pengelola berasumsi bahwa sampah tersebut telah tertinggal di dalam kawasan, wisatawan wajib kembali lagi kedalam kawasan dan mencari sampah tersebut, apabila tidak ditemukan maka wisawan diharuskan untuk berdonasi sebersar Rp. 100.000,-/item sampah.

5. Dimensi Politik

Pengelolaan dan pengembangan kawasan CMC ini meningkatkan partisipasi dari penduduk lokal, masyarakat yang awalnya marah karena lahan tambak mereka dibebaskan oleh Yayasan Bhakti Alam Sendangbiru, namun dengan keseriusan yayasan untuk merestorasi kawasan perlahanlahan masyarakat menyadari betapa pentingnya kestabilan ekosistem lingkungan hidup, bahkan masyarakat diberi ruang untuk ikut berpartisipasi dalam pembangunan dan pengembangan, mata pencaharian mereka bertransformasi dari awalnya sebagai penambak sekarang banyak dari mereka yang telah menjadi pemandu dengan sertifikasi.

Sebagai upaya untuk meningkatkan kekuasaan komunitas lokal pengelola tidak mengizinkan adanya investasi yang berupa ruko-ruko untuk menjual makanan pada pengunjung. Untuk menjamin hak-hak dalam pengelolaan sumberdaya alam di kawasan CMC, Yayasan Bhakti Alam Sendangbiru telah mempunyai legalitas sebagai suatu lembaga yang berdasarkan 
"Surat Keputusan Menteri Hukum dan Hak Asasi Manusia Republik Indonesia Nomor AHU-15997 .AH.01.04.

\section{Pemilihan Pantai Prioritas Kawasan Clungup Mangrove Conservation}

Dalam pemilihan pantai prioritas kawasan Clungup Mangrove Conservation, telah diidentifikasi beberapa faktor yang dianggap menentukan bagi prioritas pengembangan pariwisata. Penelitian ini menitikberatkan pada empat pilihan pantai di kawasan Clungup Mangrove Conservation, yaitu (1) Pantai Clungup, (2) Pantai Sapana, (3) Pantai Mini,

(4) Pantai Batu Pecah. Ke empat pantai tersebut dipilih berdasarkan observasi di lapangan dimana ditemukan bahwa ke empat pantai tersebut belum mendapat prioritas pengembangan oleh pengelola.

\section{Penyusunan Kerangka Hirarki}

Keseluruhan struktur hirarki yang dibentuk dalam penelitian ini terdiri dari tiga level, dimana level tertinggi yang sering disebut fokus atau tujuan hanya berisi satu elemen yang merupakan tujuan dari penelitian ini, yaitu memilih destinasi pantai prioritas berdasarkan prinsip CBT.

Level berikutnya masing-masing terdiri dari beberapa elemen, dimana elemen-elemen (kriteria dan alternatif) pada tiap level harus berada pada tingkat kepentingan yang sama, karena elemen-elemen pada level yang sama akan diperbandingkan tingkat kepentingannya satu sama lain berdasarkan kriteria di atasnya.

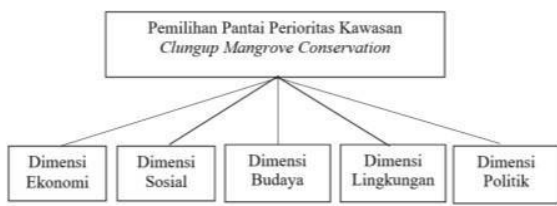

Hirarki kriteria dengan prinsip CBT Sumber: Hasil Penelitian

Level selanjutnya adalah level terakhir atau level ketiga dari tingkatan hirarki. Level terakhir ini adalah yang akan dipilih (menjadi alternatif) untuk diprioritaskan.

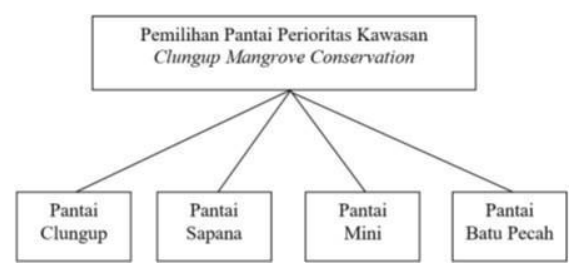

Hirarki alternatif kawasan CMC Sumber: Hasil penelitian

Kemudian setelah itu hirarki level satu sampai level tiga disusun menjadi satu kesatuan hirarki yang utuh, seperti terlihat pada gambar berikut.

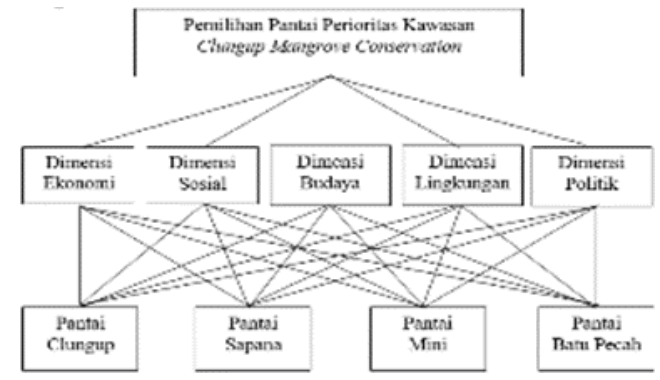

Strukut hirarki pemilihan panti prioritas kawasan CMC

Sumber: Hasil penelitian

Kerangka hirarki tersebut merupakan suatu penguraian masalah kompleks dalam kerangka mencapai tujuan penyusunan skala prioritas pemilihan pantai di kawasan $\mathrm{CMC}$, menjadi beberapa bagian hirarki yang saling berhubungan satu sama lain.

2. Menentukan Matriks Perbandingan Berpasangan (Pairwise Comparison)

tahap ini tahap pemberian bobot derajat kepentingan yang secara khusus ditentukan oleh expert. Pihak responden (expert) akan memberikan penilaian untuk mengisi seluruh matriks perbandingan berpasangan (sampai dengan level 3 dalam hirarki). Dalam menentukan matriks perbandingan berpasangan peneliti menggunakan perangkat komputer disertai dengan program expert choice 11 .

Perhitungan terhadap hasil penilaian ini menghasilkan bobot masing-masing kriteria yang berasal dari kuesioner yang ditujukkan kepada para responden (expert) di bidang pariwisata, yang telah di olah melalui program expert choice. Hasil terkait pemilihan destinasi pantai prioritas dengan prinsip community based tourism adalah dimensi lingkungan menjadi prioritas utama dalam pemilihan pantai dengan hasil AHP sebesar 0,373 membuktikan bahwa seluruh stakholders yang mengembangkan kawasan CMC lebih memilih faktor kepentingan lingkungan dibandingkan dengan faktor kepentingan lainnya. Kemudian prioritas kedua adalah kriteria ekonomi dengan hasil 
AHP sebesar 0,335 menunjukkan bahwa pengelola memperhatikan betul tingkat kesejahteraan masyarakat disekitarnya, karena dengan hadirnya pariwisata dapat menciptakan lapangan pekerjaan bagi masyarakat sekitar. Pada prioritas ketiga adalah kriteria dimensi sosial dengan hasil AHP sebesar 0,172, ini membuktikan bahwa kepentingan sosial juga turut dipertimbangkan oleh stakeholder demi terciptanya peningkatan dalam kualitas hidup. Sedangkan dimensi budaya dan dimensi politik bukanlah kepentingan yang terlalu di pertimbangkan, kedua dimensi tersebut masingmasing mendapatkan nilai sebesar 0,076 dan 0,049 .

Untuk pemilihan pantai prioritas didapati bahwa Pantai Clungup lah yang mendapatkan nilai paling besar yaitu 1,000. Pada kriteria ekonomi Pantai Clungup mendapatkan nilai 1,000, pada kriteria sosial mendapatkan 1,000, kriteria budaya mendapatkan 1,000, kriteria lingkungan mendapatkan 1,000 dan kriteria politik juga mendapatkan 1,000 .

3. Rasio Konsistensi (Consistency ratio) Consistency ratio merupakan tingkat konsistensi dalam kualitas pengambilan keputusan. Saaty (2003) menentukan jika CR mendapatkan nilai 0,10 atau kurang, maka perbandingan yang dilakukan pengambil keputusan secara relatif dapat dikatakan konsisten.

Menurut perhitungan yang dilakukan dengan program expert choice dimana nilai CR untuk antar kriteria mendapatkan nilai $(0,02)$, kriteria dimensi ekonomi sebesar $(0,02)$, kriteria dimensi sosial sebesar $(0,02)$, kriteria dimensi budaya sebesar (0,02), kriteria dimensi lingkungan sebesar $(0,02)$, dan kriteria dimensi politik sebesar (0,02). Hasil tesebut menunjukkan bahwa nilai CR pada masing-masing kriteria lebih kecil dibanding 0,10 .

Dengan demikian dapat disimpulkan bahwa perbandingan berpasangan pada pemilihan pantai prioritas di kawasan CMC adalah konsisten, sehingga nilai evaluasi terhadap kriteria-kriteria pemilihan pantai prioritas tersebut dapat diterima.

\section{PENUTUP}

\section{Simpulan}

Kawasan Clungup Mangrove Conservation dalam pengelolaannya telah menerapkan prinsip Community Based Tourism (CBT). Didalam dimensi ekonomi dengan adanya kawasan wisata CMC masyarakat mendapatkan keuntungan dengan membuka beberapa usaha meliputi homestay, rumah makan, dan ojek. Pada dimensi sosial manfaat dirasakan setelah adanya perubahan status lahan dari lahan tambak menjadi lahan konservasi dimana masyarakat semakin aktif untuk melakukan pembangunan serta semakin menjunjung tinggi semangat kekeluargaan dan kebersamaan sehingga mereka memberikan pelayanan yang baik bagi wisatawan untuk memberikan kesan sebagai tuan rumah yang baik. Pada dimensi budaya keberadaan wisatawan berdampak terhadap adanya transformasi tata nilai, dimana dahulu masyarakat menganggap bahwa wisatawan yang datang hanya biasa saja, sejak mereka mengetahui bahwa wisatawan yang datang membawa peluang dan berkah, masyaraka mulai terbuka terhadap wisatawan yang datang. Pada dimensi lingkungan pengelola menerapkan batasan kunjungan dan pengaturan sampah dengan melakukan checklist barang bawaan yang berpotensi menjadi sampah. Kemudian pada dimensi politik pengelola tidak mengizinkan adanya investasi yang berupa ruko-ruko untuk menjual makanan pada wisatawan.

Kriteria yang menjadi prioritas dalam pemilihan pantai prioritas kawasan CMC adalah dimensi lingkungan (0,373), dimensi ekonomi (0,330), dimensi sosial $(0,172)$, dimensi budaya $(0,076)$, dimensi politik $(0,049)$. Alternatif yang menjadi prioritas dalam pemilihan pantai prioritas kawasan CMC adalah Pantai Clungup dengan mendapatkan nilai $(1,000)$ pada kriteria ekonomi, $(1,000)$ pada kriteria sosial, $(1,000)$ pada kriteria budaya, $(1,000)$ pada kriteria lingkungan, dan $(1,000)$ pada kriteria politik.

Dengan demikian penelitian mengenai pemilihan pantai prioritas sebagai proses pengembangan produk pariwisata ini telah menentukan bahwa Pantai Clungup lah yang menjadi prioritas dengan kepentingan yang berada pada dimensi lingkungan, 
sehingga pengembangan produk yang nantinya akan dilakukan pengelola mendapatkan manfaat secara maksimal.

Marimin.

\section{Saran}

Berdasarkan hasil analisis, telah diketahui bahwa kawasan Clungup Mangrove Conservation memiliki pontesi yang baik untuk dikembangkan terutama Pantai Clungup, Pantai Sapana, Pantai Mini, dan Pantai Batu Pecah. Pengelolaan yang dilakukan berbasiskan pada kemasyarakatan telah sesuai dengan prinsip, walupun peran masyarakat begitu kuat dalam pengelolaan, tidak menutup kemungkinan kemudian hari terjadi halhal yang menyimpang dari pengelolaan kawasan yang berbasiskan konservasi dan masyarakat ini. Pengelola harus tetap berpegang teguh dengan budaya konservasi serta pengelolaannya yang mensejahterakan masyarakat, dan sebagai upaya untuk terus meningkatkan kapasitas diri pengelola diperlukan pelatihan-pelatihan yang terkait dengan konservasi.

\section{DAFTAR PUSTAKA}

Agus, A. 2013. Dasar-dasar Pengembangan Masyarakat Islam. IAIN Sunan Ampel Press. Surabaya.

Budiman, M. A. 2017. Identifikasi dan Pengembanan Produk Wisata Serta Kepuasan Wisatawan Terhadap Produk Wisata. Universitas Brawijaya. Malang

Bustanul, A.N. 2011. Belajar Mudah Riset Operasional. Penerbit Andi. Yogyakarta

Dahuri, R., J. 2004. Pengelolaan Sumberdaya Wilayah Pesisir dan Lautan Secara Terpadu. Edisi Revisi. Pradnya Paramita. Jakarta.

Dewi, L.G.K. 2013. Usaha Pemberdayaan Sosial Ekonomi Masyarakat Desa Beraban Dalam Pengelolaan Tanah Lot Berkelanjutan. Universitas Udayana. Bali

Dinas Kebudayaan dan Pariwisata Kabupaten Malang. 2017. Kebudayaan dan Pariwisata Kabupaten Malang dalam Angka. Malang (ID): Dinas Kebudayaan dan Pariwisata Kabupaten Malang

[KKP] Kementrian Kelautan dan Perikanan. 2011. Kelautan dan Perikanan dalam
Angka. Jakarta (ID): Kementrian Kelautan dan Perikanan

n. 2004. Teknik dan Aplikasi Pengambilan Keputusan Kriteria Majemuk. PT Grasindo. Jakarta

Moleong, L.J. 2002. Metodologi Penelitian Kualitatif. PT Remaja Rosda Karya. Bandung

Mulyono, S. 2003. Riset Operasi. Edisi Kedua. Jakarta. Lembaga Penerbit Fakultas Ekonomi Universitas Indonesia

Murphy, P.E. 1983. Tourism as a Community Industry. Journal of Tourism Management

Nurhaeni, I.D.A. 2017. Disparitas Gender Dalam Pembangunan Pariwisata Ramah Lingkungan. Universitas Sebelas Maret. Solo

Phillips. 2009. An Introduction to Community Development. Routledge. New York Pitana, I. G. 2009. Pengantar Ilmu Pariwisata.

Penerbit Andi : Yogyakarta

Prasetya, G.S. 1994. Masalah Pantai di Indonesia dan Usaha-Usaha Penangan Interinstitusi yang Pernah dan Perlu Dilakukan. Prosiding. Seminar Teknik Pantai 1993. Laboratorium Pengkajian Teknik Pantai. Badan Pengkajian dan Penerapan Teknologi (LPTP-BPP Teknologi). Yogyakarta.

Probowati, N.A. 2015. Identifikasi Faktor Penentu Pengembangan Obyek Wisata di Kabupaten Demak. Fakultas Ilmu Ekonomi. Jember. Universitas Jember

Rusdiyanti, K. 2012. Konservasi Lahan Hutan Mangrove serta Upaya Penduduk Lokal dalam Merehabilitasi Ekosistem Mangrove. Jurnal Sosiologi Pedesaan.

Saaty, T.L. 1993. Pengambilan Keputusan Bagi Para Pemimpin. Proses Hirarki Analitik Untuk Pengambilan Keputusan Dalam Situasi Yang Kompleks. PT Gramedia. Jakarta.

Sastrayuda, G.S. 2013. Strategi Pengembangan dan Pengelolaan Resort and Leisure. Universitas Pendidikan Indonesia. Bandung

Suansri, P. 2003. Community based Toursim Handbook. Bangkok, Thailand: Responsible Ecological Social Tours (REST) Project.

Subardin, F.N. 2010. Penentuan Prioritas Pengembangan Wisata Alam di Kabupaten Lebak. Fakultas Teknik. Universitas Pasundan. Bandung

Suharsimi. 2013. Prosedur Penelitian: Suatu Pendekatan Praktik. Rineka Cipta Jakarta 
Sugiyono. 2009. Metode Penelitian Kuantitatif, Kualitatif dan R\&D. Alfabeta. Bandung

Sukmadinata, N.S. 2007. Metode Penelitian Pendidikan. PT Remaja Rosdakarya. Bandung

Sunaryo, B. 2013. Kebijakan Pembangunan Destinasi Pariwisata Konsep dan Aplikasinya di Indonesia. Gava Media. Yogyakarta

Suwantoro, G. 2004. Dasar-Dasar Pariwisata.

Penerbit Andi. Yogyakarta

Spillane, J. J. 1987. Ekonomi Pariwisata Sejarah dan Prospeknya. Kanisius. Yogyakarta

Undang-Undang Republik Indonesia No. 10 Tahun 2009 Tentang Kepariwisataan.

Yachya, A.N. 2016. Pengelolaan Kawasan Wisata Sebagai Upaya Peningkatan ekonomi Masyarakat Berbasis CBT (Community Based Tourism). (Studi Pada Kawasan Wisata Pantai Clungup Kabupaten Malang). Universitas Brawijaya. Malang.

Yoeti, O.A. 2008. Ekonomi Pariwisata. Jakarta: Kompas.

Yoeti, O.A 1997. Perencanaan dan Pengembangan Pariwisata. PT. Pradyana Paramita (cetakan pertama). Jakarta. 